\title{
Auditor Change Disclosures as Signals of Earnings Management and Risk
}

February 2, 2018

\begin{abstract}
Auditor resignations are considered more negative signals than auditor dismissals, but firms' self-reported distinction between the two may not offer a complete or reliable representation of the nature of the auditor change. 8-K regulations require the disclosure of the adjournment of an audit engagement even if a successor auditor has not yet been named. In compliance with this requirement, some firms file two 8-k's related to the same auditor change. Exploiting these dual 8-K filings, we create a new measure of the nature of auditor changes and show that 1) both self-reported auditor resignations and dual 8-K filings are related to measures of earnings management and risk; and 2) auditor changes identified as both self-reported resignations and dual 8-K filings are associated with the most negative economic implications (as reflected by the likelihood of financial statement manipulation and bankruptcy risk). We suggest that dual 8-K filings and self-reported resignations are complementary negative signals each capturing unique dimensions of the underlying economic factors.
\end{abstract}

Keywords: Auditor Dismissal, Resignation, 8-K Disclosures, Earnings Management, Risk 


\section{Introduction}

Firms are required to file an 8-K with the Securities and Exchange Commission (SEC) within four days of an auditor change and to disclose whether the firm dismissed the auditor or the auditor resigned (or declined to stand for re-appointment). In general, auditor resignations are considered worse signals than auditor dismissals. Anecdotally, auditor resignations are more likely caused by disagreements between the auditor and management (e.g., Business Week, 1993; MacDonald, 1997). Academic research also confirms this to be the case. ${ }^{1}$ For example, Wells and Loudder (1997) find negative stock price movements in response to auditor resignations but not to auditor changes in general.

In contrast, auditor dismissal is more likely to result from valid economic or operational reasons such as the promise of better services, industry specialization, lower audit fees, etc., or simply firm policy of changing auditors every several years (Grothe and Weirich, 2007). This distinction between auditor dismissals and resignations, however, is highly political and may not necessarily be reliably inferred from firms' self-reported designation. In fact, as specified by Item 304 (a) of Regulation S-K, the SEC requires firms to elaborate on the circumstances surrounding the auditor change to address the concerns that firms might intentionally obfuscate auditor resignations. Still, in some cases, the officially reported designation may not best reflect the true circumstances of the auditor change. For example, a client may dismiss its auditor simply to preempt the auditor's impending or feared resignation. In other cases, the auditor may provide the client significant notice of its intention to resign, allowing the client to prepare for the change and secure a new auditor. The former example may be a far worse signal than the latter, despite only the latter being reported as a resignation.

Given the unreliable distinction between auditor dismissals and resignations, we exploit the difference between dual and single 8-K filings and argue that this distinction may provide additional insight into the nature of the auditor change and the degree to which it provides a negative signal. Auditor changes are reported in 8-K filings under Item 4.01, Changes in Registrant's Certifying

\footnotetext{
${ }^{1}$ See Boone and Raman (2001) for a more detailed summary of the difference between auditor resignations and dismissals examined by academic studies. The study notes that "the implication is that auditor dismissals are viewed neutrally and not as a symptom of opinion shopping intended to undermine the integrity of the independent audit; by contrast, resignations appear to be viewed negatively by investors."
} 
Accountant. In compliance with the disclosure requirement for this item, in some cases, firms file a single 8-K disclosing that they will no longer engage the incumbent auditor and instead will engage a new audit firm (for an example, see Exhibit 1a). In other cases, there is a lag between these two disclosures: firms file an initial 8-K that discloses the end of the engagement with the existing auditor, and days or weeks later, they file a second 8-K disclosing the engagement of a new auditor (for an example, see Exhibit 1b). ${ }^{2}$

Lynch (2008) exploits this distinction between single and dual 8-K filings and finds a significant negative market response when firms file an initial 8-K disclosing a change in auditor without naming a new auditor. In contrast, there is no abnormal return upon single 8- $\mathrm{K}$ filings that simultaneously announce the end of a relationship with the incumbent auditor and the engagement of a new auditor. Given this disparate market response to single and dual 8-K filings and the intuition that dual filings imply the client's lack of preparedness for the auditor change, we interpret dual 8-K filings as particularly negative types of auditor changes. We argue that dual 8-K filings may indicate disagreement between the auditor and management or opinion shopping by the firm, both of which are negative signals of firm fundamentals. In this paper, we consider self-reported resignations and dual 8-K filings separately, as well as cases in which the two occur together. We expect both self-reported resignations and dual 8-K filings to be separately associated with negative circumstances and the intersection between them to identify the most negative cases. Figure 1 illustrates circumstances we conjecture may underlie the various combinations of selfreported auditor changes and 8-K filings.

Our first objective is to test whether measures of firms' earnings management, bankruptcy risk, and litigation risk are associated with auditor changes in general. ${ }^{3}$ Consistent with prior literature (e.g., Bradshaw et al., 2001), we find that auditor changes overall are not associated with discretionary accruals. However, when we analyze positive and negative discretionary accruals separately,

\footnotetext{
${ }^{2}$ According to the SEC's 8-K disclosure guidelines, "the resignation or dismissal of an independent accountant, or its refusal to stand for re-appointment, is a reportable event separate from the engagement of a new independent accountant. On some occasions, two reports on Form 8-K are required for a single change in accountants, the first on the resignation (or refusal to stand for re-appointment) or dismissal of the former accountant and the second when the new accountant is engaged. Information required in the second Form $8-\mathrm{K}$ in such situations need not be provided to the extent that it has been reported previously in the first Form 8-K." Source: https://www.sec.gov/files/form8-k.pdf

${ }^{3}$ Ghosh and Tang (2015) finds that litigation risk, audit risk, and business risk are associated with auditor resignations. We confirm and extend these results by examining dual 8-K filings as well, a signal of negative circumstances surrounding an auditor change that is distinct from but complementary to resignation. In addition, we explicitly and separately test measures of earnings management that comprise Ghosh and Tang (2015)'s composite measure.
} 
we find that auditor changes are associated with positive discretionary accruals. This finding is contrary to Lustgarten and Shon (2013), which finds that auditor changes are associated with both positive and negative discretionary accruals. Additionally, we find that auditor changes are more likely when the likelihood of financial statement manipulation is high (as measured following Beneish (1999)) and when bankruptcy risk is high (as measured following Altman (2000)). Auditor changes are less likely when accrual quality is high (as measured following Dechow and Dichev (2002)) and when auditor tenure is longer.

Our second objective is to examine factors associated with the more negative types of auditor changes identified by self-reported resignations and dual 8-K filings. Consistent with the untested prediction of Lustgarten and Shon (2013), we find that both self-reported resignations and dual 8-K filings are more likely when discretionary accruals are high and less likely when discretionary accruals are low. In addition, self-reported resignations are positively associated with bloated balance sheets and with litigation risk (both measured following Ho et al. (2012)). Dual 8-K filings are positively associated with the likelihood of financial statement manipulation and negatively associated with accrual quality. Overall, both dual 8-K filings and self-reported resignations are associated with measures of accounting manipulation, but in complementary ways.

Our third objective is to test whether concurrent self-reported resignations and dual 8-K filings (i.e. the bottom right quadrant in Figure 1) identify particularly negative situations. Specifically, we exploit both the distinction between single and dual 8-K filings and firms' self-reported resignation or dismissal distinction simultaneously to create a novel measure that better captures the negative economic implications of these types of auditor changes. We find that the positive association between the likelihood of financial statement manipulation and either of the two measures is driven by cases in which the two measures agree (i.e., there is both a dual 8-K filing and a self-reported auditor resignation). Similarly, a higher likelihood of bankruptcy is positively associated with auditor changes in which both a self-reported resignation and a dual 8-K filing occur but not with either condition separatley.

The contribution of our paper is threefold. First, we contribute to the existing literature by calling attention to the distinction between single and dual 8-K filings for auditor changes that is first documented by Lynch (2008) but subsequently ignored by the literature. We show that 
dual 8-K filings are a negative signal, particularly when they occur contemporaneously with selfreported auditor resignations. Second, we investigate an untested mechanism underlying auditor changes suggested in Lustgarten and Shon (2013) as well as other potential differential determinants of single versus dual 8-K filings and self-reported resignations versus dismissals. Third, we show that utilizing both the dual 8-K filing measure and the firm-reported auditor resignation measure better identifies negative conditions related to accounting manipulation and bankruptcy risk. Our measure is complementary to that of the prior literature in capturing different dimensions of the sources of auditor changes.

The remainder of this paper is structured as follows. Section 2 discusses prior studies and develops hypotheses. Section 3 introduces our research. Section 4 provides details of sample selection and variables of interest. Section 5 presents the empirical results. Finally, Section 6 concludes.

\section{Prior Literature and Hypothesis Development}

Conceptually, there are two types of auditor changes: those that are initiated by the client and those that are initiated by the auditor. Explicit disclosures by the firm may not fully convey to which category an auditor change belongs. Calderon et al. (2011) find that "companies use boilerplate language and adopt a check-the-box approach to compliance with Regulation S-K 304. Contrary to the spirit and intent of corporate governance, their disclosures generally lack transparency and offer little or no insight into the underlying reasons for auditor changes." Dunn et al. (1999) find a similar phenomenon in British firms, noting that "very few auditors indicate there were problems of which the shareholders and creditors should be made aware" in their resignation letters. This points to a lack of informativeness of explicit auditor change disclosures that occurs across various regulatory regimes. Scholz (2003) suggests that "some dismissals are implicit resignations." Finally, Burks and Sustersic (2017) note the ambiguity in reported auditor dismissals and suggests timing within the accounting period as an alternative signal.

Because the officially disclosed resignation or dismissal designation may not provide a complete or credible indication as to which party initiated the change, we suggest a complementary signal 
identified by prior literature and show that it captures slightly different dimensions of the determinants of auditor changes. Lynch (2008) is the first and, to our knowledge, only paper to identify another binary classification of auditor change disclosures: those reported in a single 8-K filing and those reported in dual 8-K filings. Single 8-K filings simultaneously disclose the end of the incumbent auditor's engagement with the client and the engagement of a new auditor. In dual 8-K filings, an initial filing discloses the end of the incumbent auditor's engagement, and a second filing days or weeks later discloses the engagement of a new auditor. Dual 8-k filings for auditor changes are associated with a $-2.28 \%$ abnormal return on the date of the first 8 -K filing date and only a slight recovery on the second $8-\mathrm{K}$ filing date. The market response is most negative for dual 8-K filings that are reported as auditor resignations (-2.86\%), followed by dual 8-K filings reported as auditor declinations to stand for reelection (-2.04\%), and least negative for dual 8-K filings reported as client dismissals of the auditor (-1.06\%). In contrast, Lynch (2008) finds no significant abnormal return on the date of single 8-K filings for auditor changes.

In fact, Smith (1988) cites the conceptual difference in information content between these two events as a key reason the SEC changed the event triggering an 8-K filing from the hiring of a new auditor to the end of the incumbent audit engagement. Smith writes, "The Securities and Exchange Commision claims that prior to 1975 auditor change Form 8-K filings may have been associated with firm-delayed disclosures of 'bad news.' In Accounting Series Release (ASR) No. 165 the SEC states that 'in the past, when only the engagement of a new accountant triggered the reporting requirement, there was sometimes considerable delay in bringing significant disagreements to the attention of investors' (SEC Docket, 1974). Also, a firm which delayed hiring a new auditor, and so delayed disclosing the auditor change, could not be differentiated from a firm finding a new auditor right away since the date a firm fired the predecessor auditor was not disclosed." Smith (1988) also notes that many auditor changes prior to the SEC's rule change that were not reported immediately upon the end of the incumbent engagement were "involuntary on the part of the client firm," as determined by the text of the 8-K and coverage in the Wall Street Journal.

Our paper builds on Lynch (2008) and Smith (1988) in several ways. First, we draw attention to the distinction between single and dual 8-K filings for auditor changes and suggest that in complement to self-reported resignations, auditor changes reported using dual 8-K filings can be 
interpreted as particularly negative types of auditor changes. As shown in Lynch (2008), the market identifies auditor changes disclosed using dual 8-K filings as negative signals, but accounting researchers have almost entirely ignored this phenomenon. Several studies, on the other hand, have shown the negative market consequences of auditor resignations (Hertz, 2006; Shu, 2000; Wells and Loudder, 1997). In this paper, we show that especially when dual 8-K filings and self-reported auditor resignations occur together, they are able to identify very negative situations. Second, we focus on the determinants of different types of auditor changes, whereas Lynch (2008) focuses on the capital market reactions to them. Lastly, we examine how self-reported resignations and dual 8-K filings are associated with the likelihood of financial statement manipulation and bankruptcy risk. This analysis allows us to reflect on possible reasons for the negative market implications of dual 8-K filings identified in Lynch (2008) and to examine the implications of contemporaneous self-reported resignations and dual 8-K filings.

Evidence on the association between auditor changes and earnings management is mixed. On the one hand, prior studies have suggested that auditor changes may be related to earnings management. Fried and Schiff (1981) suggest that clients might "shop around" for an auditor that is likely to defer to the client's wishes or accounting preferences in an effort to manage earnings, and Keasey and Watson (1991) finds some support for this claim among small UK firms. Woo and Koh (2001) finds that "auditor changes are more likely in cases where firms ... experience an increase in income manipulation opportunities." Additionally, Sengupta and Shen (2007) finds that "poorer accruals quality is associated with... a greater likelihood of auditor turnover." On the other hand, Williams (1988) notes that one "possible motive for retaining an established auditor concerns client/auditor agreements about accounting policies that have occurred over the years. If a new auditor were hired, the existing accounting policies might come under close scrutiny, and a potential confrontation could arise with the new auditor", which implies a negative association with earnings management and auditor change. Davidson et al. (2006) finds that "on average, earnings management does not increase following auditor changes." Davis et al. (2009) find that in the post-Sarbanes-Oxley period, discretionary accruals are not related to auditor tenure, although the two are related in the pre-Sarbanes-Oxley period. Bradshaw et al. (2001) finds no evidence that auditor changes are related to the level of accruals. Therefore, the relationship between auditor 
changes and earnings management remains an open question in the literature.

Several prior studies have examined the association between auditor changes and risk, focusing on the subset of auditor changes that are reported as auditor resignations, and found positive associations between self-reported resignations and litigation risk (DeFond et al., 1997; Hertz, 2006; Krishnan and Krishnan, 1997, Shu, 2000) and bankruptcy risk (DeFond et al., 1997; Krishnan and Krishnan, 1997). Additionally, Liang and Lyu (2016) find that conditional conservatism is negatively associated with auditor resignations but that effective corporate governance moderates this effect, and Goh et al. (2013) finds that auditor resignations are positively associated with tax aggressiveness.

Prior studies have also shown auditor resignations (Ghosh and Tang, 2015) and dismissals (DeFond and Subramanyam, 1998) to be related to discretionary accruals. To the best of our knowledge, Lustgarten and Shon (2013) is the only paper to explicitly hypothesize that abnormal accruals are related differently to auditor resignations than dismissals. They find that auditor changes are associated with both positive and negative discretionary accruals and suggest that auditors and clients undergo a negotiation process in setting discretionary accruals. Auditors are thought to prefer low discretionary accruals to minimize litigation risk, and clients are thought to prefer high discretionary accruals to improve reported performance. They then suggest that auditors may resign when the client succeeds in reporting high (i.e., income-increasing) discretionary accruals and that clients may dismiss auditors if they impose low (i.e., income-decreasing) discretionary accruals on the firm. However, the paper's formal hypotheses and empirical tests focus on the expected life of audit engagements, essentially grouping resignations and dismissals together. Our paper explicitly analyzes the untested reasoning of Lustgarten and Shon (2013), augmenting it with the findings of prior literature to test for other differential sources of self-reported auditor resignations and dismissals and expanding to examine not only resignations and dismissals, but also single and dual 8-K filings. Formally, we hypothesize that:

H1: Auditor changes are associated with positive and negative abnormal accruals.

H2a: Measures of earnings management, including the magnitude of positive abnormal accruals, are positively associated with the likelihood of self-reported auditor resignation and dual 8-K filing.

H2b: The magnitude of negative abnormal accruals is positively associated with the likelihood 
of self-reported auditor dismissal and single 8-K filing.

Further, auditor resignations and dual 8-K filings are considered negative signals. Two possible explanations for these negative implications are the increased likelihood of financial statement manipulation and bankruptcy risk. Griffin and Lont (2010) finds that the negative market response to auditor resignations is especially large for firms with prior securities litigation and higher bankruptcy risk. The market interprets both auditor resignations and dual 8-K filings as negative signals. Resignations may indicate disagreements between auditor and client or some malfeasance by the client, whereas dual 8-K filings imply the client's unpreparedness for the auditor change and raise uncertainty about the change. While these two situations may overlap, they do not necessarily coincide and might each capture unique dimensions of the underlying fundamental factors. Therefore, we propose that taking the intersection of the two measures (i.e., situations in which there is both a self-reported auditor resignation and a dual 8-K filing) should yield a superior measure that presents an even stronger negative signal. Formally, we hypothesize that:

H3a: The likelihood of financial statement manipulation is positively associated with selfreported auditor resignation and dual 8-K filing but most strongly associated with the combination of self-reported auditor resignation and dual 8-K filing.

H3b: Bankruptcy risk is positively associated with self-reported auditor resignation and dual 8-K filing but most strongly associated with the combination of self-reported auditor resignation and dual 8-K filing.

\section{$3 \quad$ Research Design}

We begin by analyzing the determinants of auditor changes, focusing on several measures of earnings management and controlling for other determinants following Lustgarten and Shon (2013). We estimate the following two equations: 


$$
\begin{aligned}
A U D C H G_{i t} & =\alpha_{0}+\alpha_{1} A B S \_D A_{i t-1}+\alpha_{2} M A N I P U L A T E_{i t-1}+\alpha_{3} A C C \_Q U A L_{i t-1}+\alpha_{4} N O A_{i t-1} \\
& +\alpha_{5} B A N K R \_R I S K_{i t-1}+\alpha_{6} L I T_{i t-1}+\alpha_{7} N O N S T D_{i t-1}+\alpha_{8} M T B_{i t-1} \\
& +\alpha_{9} T E N U R E_{i t-1}+\alpha_{10} B I N G N_{i t-1}+\alpha_{11} A G E_{i t-1}+\alpha_{12} A T_{i t-1}+\varepsilon_{i t}
\end{aligned}
$$

$$
\begin{aligned}
A U D C H G_{i t} & =\alpha_{0}+\alpha_{1} A B S \_P O S \_D A_{i t-1}+\alpha_{2} A B S \_N E G_{\_} D A_{i t-1}+\alpha_{3} M A N I P U L A T E_{i t-1} \\
& +\alpha_{4} A C C \_Q U A L_{i t-1}+\alpha_{5} N O A_{i t-1}+\alpha_{6} B A N K R \_R I S K_{i t-1}+\alpha_{7} L I T_{i t-1} \\
& +\alpha_{8} N O N S T D_{i t-1}+\alpha_{9} M T B_{i t-1}+\alpha_{10} T E N U R E_{i t-1}+\alpha_{11} B I N G N_{i t-1} \\
& +\alpha_{12} A G E_{i t-1}+\alpha_{13} A T_{i t-1}+\varepsilon_{i t}
\end{aligned}
$$

In Equation (1), $A U D C H G_{i t}$ is an indicator variable that equals one if firm $i$ reported an auditor change in year $t$ and zero otherwise. We regress $A U D C H G_{i t}$ on a battery of factors that have been identified as predictors of auditor changes by the prior literature. All independent variables are lagged since the auditor and client cannot observe their current-year values prior to any resignation or dismissal in the current year. $A B S \_D A_{i t-1}$ is the absolute value of discretionary accruals, estimated from a modified Jones model, scaled by lagged total assets. $M A N I P U L A T E_{i t-1}$ is an indicator variables that equals one if the Beneish M-score is greater than -2.2 and zero otherwise, which captures the likelihood that a firm's reported earnings have been manipulated. $A C C \_Q U A L_{i t-1}$ is accrual quality based on Dechow and Dichev (2002). NOA $A_{i t-1}$ captures "bloated balance sheet," which Barton and Simko (2002) finds to reflect the extent of previous earnings management. $B A N K R \_R I S K_{i t-1}$ is an indicator variable that equals one if the Altman's Z-score is less than 1.8 and zero otherwise, which captures bankruptcy risk. $L I T_{i t-1}$ is an indicator variable that equals one if the observation falls into one of the industries identified by Ho et al. (2012) as having high litigation risk and zero otherwise. NONSTD $D_{i t-1}$ is an indicator variable that equals one if the firm received a non-standard audit opinion and zero otherwise. $M T B_{i t-1}$ is the firm's market value of equity divided by the book value of equity. TENURE $E_{i t-1}$ 
reflects the auditor's tenure with the client which takes integer values from one to 10 indicating the number of years the auditor has been engaged with the client. ${ }^{4} B I N G N_{i t-1}$ is an indicator variable that equals one if the auditor is a Big-N firm and zero otherwise. $A G E_{i t-1}$ is firm age measured as the time since its initial public offering. $A T_{i t-1}$ is total assets. Appendix A provides detailed variable definitions.

In Equation (2), $A B S \_D A_{i t-1}$ is replaced by $A B S \_P O S \_D A_{i t-1}$ and $A B S \_N E G \_D A_{i t-1}$. $A B S \_P O S \_D A_{i t-1}\left(A B S \_N E G \_D A_{i t-1}\right)$ is the absolute value of the positive (negative) discretionary accruals when the discretionary accruals are positive (negative), and zero otherwise.

Next, we restrict our sample to only firm-years with auditor changes and examine the determinants of dual 8-K filings and self-reported auditor resignations, the two types of auditor changes identified as negative by prior literature. We estimate the following equation:

$$
\begin{aligned}
R E S I G N_{i t} \text { or DUAL_8 } K_{i t} & =\alpha_{0}+\alpha_{1} A B S \_P O S \_D A_{i t-1}+\alpha_{2} A B S \_N E G_{-} D A_{i t-1} \\
& +\alpha_{3} M A N I P U L A T E_{i t-1}+\alpha_{4} A C C_{-} Q U A L_{i t-1} \\
& +\alpha_{5} N O A_{i t-1}+\alpha_{6} B A N K R \_R I S K_{i t-1}+\alpha_{7} L I T_{i t-1} \\
& +\alpha_{8} N_{\text {NONST }} D_{i t-1}+\alpha_{9} M T B_{i t-1} \alpha_{10} T E N U R E_{i t-1} \\
& +\alpha_{11} \text { BINGN }_{i t-1}+\alpha_{12} A G E_{i t-1}+\alpha_{13} A T_{i t-1}+\varepsilon_{i t}
\end{aligned}
$$

$R E S I G N_{i t}$ is an indicator variable that equals one if the auditor change was self-reported as an auditor resignation and zero otherwise. $D U A L \_8 K_{i t}$ is an indicator variable that equals one if the firm reported the auditor change using dual 8-K filings and zero if it reported the change using a single 8-K filing. The independent variables are exactly the same as in Equation (2).

Lastly, we examine how dual 8-K filings and self-reported resignations relate to the likelihood of financial statement manipulation and bankruptcy risk, two potential reasons for the market's negative reaction to these types of auditor change disclosures. We exploit the distinction between single and dual 8-K filings as well as firms' self-reported resignation or dismissal distinction to create a novel measure that better captures the negative economic implications of these types of

\footnotetext{
${ }^{4} \mathrm{~A}$ value equal to 10 indicates that the auditor has been engaged with the client for 10 or more years.
} 
auditor changes. We estimate the following two equations:

$$
\begin{aligned}
\text { MANIPULATE }_{i t} & =\alpha_{0}+\alpha_{1} D U A L \_8 K_{i t+1}+\alpha_{2} R E S I G N_{i t+1}+\alpha_{3} D U A L \_A N D \_R E S I G N_{i t+1} \\
& +\alpha_{4} A B S \_P O S \_D A_{i t-1}+\alpha_{5} A B S \_N E G_{\_} D A_{i t-1}+\alpha_{6} A C C_{-} Q U A L_{i t-1} \\
& +\alpha_{7} N O A_{i t-1}+\alpha_{8} B A N K R \_R I S K_{i t-1}+\alpha_{9} L I T_{i t-1}+\alpha_{10} N O N S T D_{i t-1} \\
& +\alpha_{11} M T B_{i t-1}+\alpha_{12} T E N U R E_{i t-1}+\alpha_{13} B I N G N_{i t-1}+\alpha_{14} A G E_{i t-1} \\
& +\alpha_{15} A T_{i t-1}+\varepsilon_{i t}
\end{aligned}
$$

$$
\begin{aligned}
B A N K R \_R I S K_{i t} & =\alpha_{0}+\alpha_{1} D U A L \_8 K_{i t+1}+\alpha_{2} R E S I G N_{i t+1}+\alpha_{3} D U A L \_A N D \_R E S I G N_{i t+1} \\
& +\alpha_{4} A B S \_P O S \_D A_{i t-1}+\alpha_{5} A B S \_N E G_{-} D A_{i t-1}+\alpha_{6} A C C \_Q U A L_{i t-1} \\
& +\alpha_{7} N O A_{i t-1}+\alpha_{8} M A N I P U L A T E_{i t-1}+\alpha_{9} L I T_{i t-1}+\alpha_{10} N O N S T D_{i t-1} \\
& +\alpha_{11} M T B_{i t-1}+\alpha_{12} T E N U R E_{i t-1}+\alpha_{13} B I N G N_{i t-1}+\alpha_{14} A G E_{i t-1} \\
& +\alpha_{15} A T_{i t-1}+\varepsilon_{i t}
\end{aligned}
$$

$D U A L \_A N D \_R E S I G N_{i t+1}$ is $D U A L \_8 K_{i t+1}$ multiplied by $R E S I G N_{i t+1}$ and all other independent variables are defined as before.

\section{Sample Selection and Variables of Interest}

We collect our auditor change variables from Audit Analytics from fiscal years 2000 (the first year for which data are available) to 2016. We collect other accounting variables from Compustat over the same period. After merging the two databases, we obtain a main sample of 81,691 observations including 3,186 auditor changes.

Among the firm-years that experienced auditor changes, we consider two metrics that differentiate negative types of auditor changes, both of which are constructed with data readily available from Audit Analytics. First, we identify self-reported auditor resignations with the variable $R E S I G N_{i t}$ 
(labeled as "auditor_resigned" in Audit Analytics). This variable is an indicator variable that equals one if the firm reports the auditor change as an auditor resignation and zero otherwise. Second, we construct $D U A L \_8 K_{i t}$, an indicator variable that equals one if "dismiss_date" and "engage_date" from Audit Analytics are different and zero if they are the same. These two dates correspond to the date when the existing auditor ceases its role and the date when the successor auditor is engaged. In our sample, among cases where the two dates differ, the median lag between them is 14 calendar days, and the lag is over 43 calendar days for $25 \%$ of the cases. Of the 3,186 auditor changes in our sample, 724 are self-reported resignations and 944 are disclosed through dual 8-K filings. The correlation between $R E S I G N_{i t}$ and $D U A L \_8 K_{i t}$ is 0.36 . Figure 1 illustrates the allocation of auditor changes across these two metrics. The data suggest that although the information reflected in $R E S I G N_{i t}$ and $D U A L \_8 K_{i t}$ overlaps, the two metrics each capture some unique information. As such, the agreement between these two metrics contains more information than either measure alone, and, as suggested by our empirical results, identifies those auditor changes (i.e. the right bottom quadrant in Figure 1) with the most negative economic implications.

Panel A of Table 1 reports the univariate statistics for our main variables. $A B S \_P O S \_D A_{i t}$ and $A B S \_N E G \_D A_{i t}$ are comparable in magnitude, with $A B S \_P O S \_D A_{i t}$ being slightly larger. Over half of our sample has high earnings manipulation risk as measured by Beneish M-score (MANIPULATE $\left.E_{i t}\right)$, while about $20 \%$ of our sample has high bankruptcy risk (BANKR_RISK $\left.K_{i t}\right)$. Panel B of Table 2 reports the Pearson (Spearman) correlations between variables below (above) the diagonal. Firms' self-reported resignation designation $\left(R E S I G N_{i t}\right)$ is only positively correlated with the magnitude of negative accruals, while dual 8-K filings $\left(D U A L \_8 K_{i t}\right)$ are only correlated with the magnitude of unsigned accruals as measured by Spearman correlations. While RESIGN $N_{i t}$ is positively correlated with bankruptcy risk, such correlation is observed for $D U A L \_8 K_{i t}$ only in terms of Spearman correlations.

\section{$5 \quad$ Empirical Results}

The results of estimating Equations (1) and (2) are presented in Table 2. Column 1 presents the relationship between auditor changes and discretionary accruals; Column 2 presents this rela- 
tionship for positive and negative discretionary accruals separately. Column 1 shows that auditor changes are not associated with discretionary accruals in aggregate; Column 2, however, reveals that auditor changes are significantly associated with positive discretionary accruals, providing only partial support for H1. This result differs from that of Lustgarten and Shon (2013), which finds that auditor changes are associated with both positive and negative discretionary accruals. In both specifications, auditor changes are associated with a high likelihood of financial statement manipulation as measured by the Beneish M-score (MANIPULATE $\left.E_{i t-1}\right)$. Auditor changes are also more likely when bankruptcy risk $\left(B A N K R \_R I S K_{i t-1}\right)$ is high. Auditor changes are less likely when accrual quality $\left(A C C \_Q U A L_{i t-1}\right)$ is high and when auditor tenure $\left(T E N U R E_{i t-1}\right)$ is longer.

The results of estimating Equation (3) are presented in Table 3. Column 1 relates to dual 8-K filings $\left(D U A L \_8 K_{i t}\right)$ and Column 2 to self-reported auditor resignations $\left(R E S I G N_{i t}\right)$. Table 3 reveals that both dual 8-K filings and self-reported resignations are more likely when discretionary accruals are high (positive) and less likely when discretionary accruals are low (negative). This is consistent with the untested prediction from Lustgarten and Shon (2013), which suggests that auditors resign in response to high discretionary accruals $\left(A B S \_P O S \_D A_{i t-1}\right)$ and that clients dismiss their auditors in response to low discretionary accruals $\left(A B S \_N E G \_D A_{i t-1}\right)$. Dual 8-K filings are also more likely when the likelihood of financial statement manipulation is high and marginally less likely when accrual quality is high. Self-reported auditor resignations, on the other hand, are more likely when net operating assets are higher (i.e., when the balance sheet is bloated) and in industries in which litigation risk is high. ${ }^{5}$ Across these dimensions, the results for dual 8-K filings and self-reported resignations differ. Overall, both dual 8-K filings and self-reported resignations are associated with measures of earnings management, misreporting, and risk, but in different ways. Our results are consistent with $\mathrm{H} 2$ and suggest that dual 8-K filings and self-reported auditor resignations may play complementary roles in identifying high-risk firms.

Next, Table 4 presents the results of estimating Equations (4) and (5), which examine the relationship between two key risk metrics, dual 8-K filings, and self-reported resignations, with a

\footnotetext{
${ }^{5}$ Variable $N O N S T D_{i t-1}$ dropped out from the right-hand side because none of the firm-years in this sample received a non-standard audit opinion.
} 
special focus on the cases in which both dual 8-K filings and self-reported resignations occur. ${ }^{6}$ Column 1 reveals that subsequent dual 8-K filings $\left(D U A L \_8 K_{i t+1}\right)$ reflects the likelihood of financial statement manipulation in prior year, but this is not the case for self-reported resignations $\left(R E S I G N_{i t+1}\right)$. In Column 2, when we include DUAL_AND_RESIGN $N_{i t+1}$, the intersection of $D U A L \_8 K_{i t+1}$ and $R E S I G N_{i t+1}$, we find that only auditor changes reported as resignations and using dual 8-K filings are associated with a high likelihood of prior financial statement manipulation. 7 In addition, firm-years with large (positive or negative) discretionary accruals and with bloated balance sheets are more likely to be flagged as likely manipulators. Firm-years with big-N auditors and longer auditor tenure are less likely to be suspected of having manipulated financial statements. Lastly larger firms (as measured by total assets) are more likely to be suspected of financial statement manipulation. Possibly, this association reflects financial sophistication and thus the ability to manage earnings.

Columns 3 and 4 of Table 4 reveal that neither subsequent dual 8-K filings nor self-reported resignations is positively associated with prior year's bankruptcy risk on its own. Only when dual 8-K filings and self-reported resignations occur together is bankruptcy risk significantly higher. Bankruptcy risk is significantly higher among firm-years with large positive or negative discretionary accruals, firm-years with bloated balance sheets, and when litigation risk is high. Bankruptcy risk is lower among firm-years with big-N auditors and counterintuitively, higher among firm-years with higher accrual quality. Contrary to H3, neither self-reported resignation nor dual 8-K filing alone reflects prior year's bankruptcy risk. These results provide even stronger support than expected for the use of our combined measure, $D U A L \_A N D \_R E S I G N_{i t+1}$.

\section{Conclusion}

Both dual 8-K filings and self-reported auditor resignations can indicate negative circumstances surrounding an auditor change. Consistent with this intuition, we find that both dual 8-K filings and self-reported auditor resignations are positively associated with income-increasing discretionary

\footnotetext{
${ }^{6}$ In untabulated analysis, we confirm that our results hold using an alternative regression specification: regressing an indicator variable that equals 1 if the auditor change is self-reported as a resignation and using dual 8-K filings in year $\mathrm{t}+1$ on $M A N I P U L A T E_{i t}$ and $B A N K R \_R I S K_{i t}$, with the same set of explanatory variables as in Table 4.

${ }^{7}$ In untabulated analysis, we find that individually, dual 8-K filings and self-reported resignations are insignificantly associated with the likelihood that the prior year's financial statements were manipulated.
} 
accruals and negatively associated with income-decreasing discretionary accruals. In addition, dual 8-K filings are positively associated with Beneish's M-score and negatively associated with accrual quality. Self-reported resignations are positively associated with bloated balance sheets and litigation risk.

We also hypothesize and find that when self-reported auditor resignations and dual 8-K filings occur together, they identify the most negative situations as measured by the likelihood of financial statement manipulation and bankruptcy risk. A high likelihood of financial statement manipulation (bankruptcy) is associated with auditor changes in which both a self-reported resignation and a dual 8-K filing occur but is not positively associated with either condition individually. We suggest that dual 8-K filings are a negative signal complementary to that of self-reported auditor resignations, as the two capture slightly different dimensions of the factors associated with auditor changes, and that the intersection of these two measures may be of use to researchers and stakeholders seeking to identify negative circumstances related to financial statement manipulation and bankruptcy risk. 


\section{Exhibit 1 - Examples of Auditor Change 8-K Filings}

\section{Exhibit 1A - Single 8-K Filing:}

Item 4.01 Changes in Registrant's Certifying Accountant.

On July 26, 2016, the Audit Committee of the Board of Directors (the "Audit Committee") of American Electric Power Company, Inc. ("AEP" or the "Company") determined not to renew the engagement of Deloitte \& Touche LLP, the independent registered public accounting firm, for the audits of the consolidated financial statements as of and for the fiscal year ending December 31, 2017 of AEP and its subsidiary registrants: Appalachian Power Company, Indiana Michigan Power Company, Ohio Power Company, Public Service Company of Oklahoma and Southwestern Electric Power Company. On July 26, 2016, the Audit Committee appointed PricewaterhouseCoopers LLP as the independent registered public accounting firm to audit the financial statements of AEP and its subsidiary registrants for the fiscal year ending December 31, 2017. The Audit Committee invited several accounting firms to participate in a competitive bidding process, including Deloitte \& Touche LLP. The decision to retain PricewaterhouseCoopers LLP was made by the Audit Committee. This action effectively dismisses Deloitte \& Touche LLP as the independent registered public accounting firm of AEP and its subsidiary registrants and will become effective upon Deloitte \& Touche LLP's completion of its procedures on the financial statements of AEP and its subsidiary registrants as of and for the year ending December 31, 2016 and the filing of the related Annual Report on Form 10-K, except with respect to certain other audit and audit-related services pertaining to the year ending December 31, 2016, as required by AEP.

The audit reports of Deloitte \& Touche LLP on the consolidated financial statements of AEP and its subsidiary registrants as of and for the fiscal years ended December 31, 2014 and 2015 did not contain any adverse opinion or disclaimer of opinion, nor were they qualified or modified as to uncertainty, audit scope, or accounting principles. During AEP's and its subsidiary registrants' two most recent fiscal years ended December 31, 2015, and the subsequent interim period through July 26, 2016, there were no disagreements between AEP or its subsidiary registrants and Deloitte \& Touche LLP on any matter of accounting principles or practices, financial statement disclosure, or auditing scope or procedure (within the meaning of Item 304(a)(1)(iv) of Regulation S-K) and 
there were no reportable events (as defined by Item 304(a)(1)(v) of Regulation S-K). AEP and its subsidiary registrants have requested that Deloitte \& Touche LLP furnish a letter addressed to the SEC stating whether or not it agrees with the above statements. A copy of such letter, dated July 29, 2016, is filed as Exhibit 16.1 to this Form 8-K.

During the fiscal years ended December 31, 2014 and 2015 and through the subsequent interim period July 26, 2016, AEP and its subsidiary registrants did not consult with PricewaterhouseCoopers LLP regarding any of the matters or events set forth in Item 304(a)(2)(i) or (ii) of Regulation S-K. 


\section{Exhibit 1B: Dual 8-K Filing:}

\section{Exhibit 1B.1: Initial Filing:}

Item 4.01 Changes in Registrant's Certifying Accountant

(a) On June 22, 2015, Abakan Inc.'s ("Company") independent registered public accounting firm Skoda Minotti ("Skoda") resigned as its independent registered public accounting firm.

Skoda's reports on the Company's financial statements for the years ended May 31, 2014 and May 31, 2013, contained no adverse opinion or disclaimer of opinion, and were not qualified or modified as to audit scope, or accounting principles, but as to uncertainty were qualified by Skoda's assumption that the Company would continue as a going concern.

During the Company's two most recent fiscal years and the subsequent interim period preceding Skoda's resignation there:

(i) were no "disagreements" (within the meaning of Item 304(a) of Regulation S-K) with Skoda on any matter of accounting principles or practices, financial statement disclosure or auditing scope or procedure, which disagreements, if not resolved to the satisfaction of Skoda, would have caused Skoda to make reference to the subject matter of the disagreements in its reports on the consolidated financial statements of the Company; and

(ii) no "reportable events" (as such term is defined in Item 304(a)(1)(v) of Regulation S-K).

The Company provided Skoda with a copy of this Form 8-K prior to its filing with the Securities and Exchange Commission ("Commission") and requested that Skoda furnish it with a letter addressed to the Commission stating that it agrees with the statements made above. A copy of Skoda's letter, dated June 26, 2015, is attached herewith as Exhibit 16.1 to this Form 8-K. 


\section{Exhibit 1.B.2: Second Filing:}

\section{Item 4.01 Changes in Registrant's Certifying Accountant}

(b) On July 23, 2015, upon the authorization and approval of the Board of Directors, the Company engaged Maloney + Novotny LLC ("Maloney + Novotny") as its independent registered public accounting firm.

During the Company's two most recent fiscal years and the subsequent interim period preceding Maloney + Novotny's engagement, neither the Company nor anyone acting on its behalf consulted Maloney + Novotny regarding either:

(i) the application of accounting principles to a specified transaction, either completed or proposed, or the type of audit opinion that might be rendered on the Company's consolidated financial statements, and no written report or oral advice was provided to the Company that Maloney + Novotny concluded was an important factor considered by the Company in reaching a decision as to an accounting, auditing or financial reporting issue; or

(ii) any matter that was the subject of a "disagreement" or "reportable event" (within the meaning of Item 304(a) of Regulation S-K and Item 304(a)(1)(v) of Regulation S-K respectively).

The Company provided Maloney + Novotny with a copy of this Form 8-K prior to its filing with the Commission. 


\section{References}

Altman, E. I. (2000). Predicting financial distress of companies: revisiting the z-score and zeta models. Stern School of Business, New York University, pages 9-12.

Barton, J. and Simko, P. J. (2002). The balance sheet as an earnings management constraint. The Accounting Review, 77(s-1):1-27.

Beneish, M. D. (1999). The detection of earnings manipulation. Financial Analysts Journal, $55(5): 24-36$.

Boone, J. P. and Raman, K. (2001). Auditor resignations versus dismissals: An examination of the differential effects on market liquidity and trading activity. Advances in Accounting, 18:47-75.

Bradshaw, M. T., Richardson, S. A., and Sloan, R. G. (2001). Do analysts and auditors use information in accruals? Journal of Accounting research, 39(1):45-74.

Burks, J. J. and Sustersic, S. J. (2017). Auditor dismissals: Opaque disclosures and the light of timing. SSRN.

Business Week (1993). Big six firms are firing clients. March 1:76-77.

Calderon, T. G., Ofobike, E., and Cheh, J. J. (2011). Is there transparency in auditor change disclosures? Journal of Applied Business Research (JABR), 23(3).

Davidson, W. N., Jiraporn, P., and DaDalt, P. (2006). Causes and consequences of audit shopping: an analysis of auditor opinions, earnings management, and auditor changes. Quarterly Journal of Business and Economics, pages 69-87.

Davis, L. R., Soo, B. S., and Trompeter, G. M. (2009). Auditor tenure and the ability to meet or beat earnings forecasts. Contemporary Accounting Research, 26(2):517-548.

Dechow, P. M. and Dichev, I. D. (2002). The quality of accruals and earnings: The role of accrual estimation errors. The Accounting Review, 77(s-1):35-59.

DeFond, M., Ettredge, M., and Smith, D. B. (1997). An investigation of auditor resignations. Research in Accounting Regulation, 11:25-46. 
DeFond, M. L. and Subramanyam, K. (1998). Auditor changes and discretionary accruals. Journal of accounting and Economics, 25(1):35-67.

Dunn, J., Hillier, D., and Marshall, A. P. (1999). The market reaction to auditor resignations. Accounting and Business Research, 29(2):95-108.

Fried, D. and Schiff, A. (1981). Cpa switches and associated market reactions. Accounting Review, pages $326-341$.

Ghosh, A. and Tang, C. Y. (2015). Auditor resignation and risk factors. Accounting Horizons, 29(3):529-549.

Goh, B. W., Lim, C. Y., Shevlin, T. J., and Zang, Y. (2013). Tax aggressiveness and auditor resignation. SSRN.

Griffin, P. A. and Lont, D. H. (2010). Do investors care about auditor dismissals and resignations? what drives the response? Auditing: A Journal of Practice ES Theory, 29(2):189-214.

Grothe, M. and Weirich, T. R. (2007). Analyzing auditor changes: Lack of disclosure hinders accountablility to investors. The CPA Journal, December.

Hertz, K. M. (2006). Determinants and consequences of auditor resignations and dismissals: The effect of sox. Ph.D. Thesis, University of Washington.

Ho, J. L.-C., Liu, C.-S., and Ouyang, B. (2012). Bloated balance sheet, earnings management, and forecast guidance. Review of Accounting and Finance, 11(2):120-140.

Keasey, K. and Watson, R. (1991). An agency perspective of auditor change in small firms. The Journal of Entrepreneurial Finance, 1(1):45.

Krishnan, J. and Krishnan, J. (1997). Litigation risk and auditor resignations. Accounting Review, pages $539-560$.

Liang, J. and Lyu, C. (2016). Corporate governance, conservatism and auditor resignation. SSRN.

Lustgarten, S. and Shon, J. (2013). Do abnormal accruals affect the life expectancy of audit engagements? Review of Quantitative Finance and Accounting, 40(3):443-466. 
Lynch, P. V. (2008). An empirical examination of the association between auditor change events and stock prices. Ph.D. Thesis, Rutgers University.

MacDonald, E. (1997). More accounting firms are dumping risky clients; big six worry about their reputations and chance of costly litigation. Wall Street Journal, April 25.

Scholz, S. (2003). Auditor resignations, litigation risk and litigation experience. In Advances in Financial Economics, pages 173-193. Emerald Group Publishing Limited.

SEC Docket (1974). Accounting series release number 165.

Sengupta, P. and Shen, M. (2007). Can accruals quality explain auditors' decision making? the impact of accruals quality on audit fees, going concern opinions and auditor change. SSRN.

Shu, S. Z. (2000). Auditor resignations: Clientele effects and legal liability. Journal of Accounting and Economics, 29(2):173-205.

Smith, D. B. (1988). An investigation of securities and exchange commission regulation of auditor change disclosures: The case of accounting series release no. 165. Journal of Accounting Research, pages $134-145$.

Wells, D. W. and Loudder, M. L. (1997). The market effects of auditor resignations. Auditing, 16(1):138.

Williams, D. D. (1988). The potential determinants of auditor change. Journal of Business Finance E Accounting, 15(2):243-261.

Woo, E.-S. and Koh, H. C. (2001). Factors associated with auditor changes: a singapore study. Accounting and Business Research, 31(2):133-144. 


\section{A Variable Definitions}

\begin{tabular}{|c|c|}
\hline Variables & Definitions \\
\hline$A U D C H G_{i t}$ & $\begin{array}{l}\text { An indicator variable that equals one if firm } i \text { reported an } \\
\text { auditor change in year } t \text { and zero otherwise }\end{array}$ \\
\hline$A B S_{-} D A_{i t}$ & $\begin{array}{l}\text { Absolute value of discretionary accruals, estimated from a } \\
\text { modified Jones model, scaled by lagged total assets. } \\
\text { Discretionary accruals are the residual from the following } \\
\text { equation, estimated within 2-digit SIC codes: } \\
T A_{i t}=\alpha_{0}+\alpha_{1}\left(R E V_{i t}-R E V_{i t-1}\right)+\alpha_{2} P P E_{i t}+\alpha_{3} A T_{i t-1}+\varepsilon_{i t} \\
\text { where } T A_{i t} \text { is total accruals, equal to the change in current } \\
\text { assets excluding cash minus the change in current liabilities and } \\
\text { depreciation plus the change in the current portion of long-term } \\
\text { debt. } R E V_{i t} \text { is total revenue; } P P E_{i t} \text { is gross property, plant, } \\
\text { and equipment; and } A T_{i t} \text { is total assets }\end{array}$ \\
\hline$A B S \_P O S \_D A_{i t}$ & $\begin{array}{l}\text { Discretionary accruals divided by lagged total assets if } \\
\text { discretionary accruals are greater than zero and equal to zero if } \\
\text { discretionary accruals are less than zero }\end{array}$ \\
\hline$A B S \_P O S \_D A_{i t}$ & $\begin{array}{l}\text { Absolute value of discretionary accruals divided by lagged total } \\
\text { assets if discretionary accruals are less than zero and equal to } \\
\text { zero if discretionary accruals are greater than zero }\end{array}$ \\
\hline$N O A_{i t}$ & $\begin{array}{l}\text { Stockholders' equity minus cash plus long-term debt, scaled by } \\
\text { lagged sales. This variable captures "bloated balance sheet," } \\
\text { which Barton and Simko (2002) finds to reflect the extent of } \\
\text { previous earnings management }\end{array}$ \\
\hline$M T B_{i t}$ & Market value of equity divided by book value of equity \\
\hline
\end{tabular}




\begin{tabular}{|c|c|}
\hline$M A N I P U L A T E_{i t}$ & $\begin{array}{l}\text { An indicator that equals one if the Beneish M-score is greater } \\
\text { than }-2.2 \text { and zero otherwise. The Beneish M-score captures the } \\
\text { likelihood that a firm's reported earnings have been } \\
\text { manipulated. The M-Score is equal to } \\
-4.84+0.92 D S R I+0.528 G M I+0.404 A Q I+0.892 S G I+ \\
0.115 D E P I-0.172 S G A I+4.679 T A T A-0.327 L V G I \text {, where } \\
D S R I \text { is the days sales in receivables index, GMI is the gross } \\
\text { margin index, } A Q I \text { is the asset quality index, SGI is the sales } \\
\text { growth index, } D E P I \text { is the depreciation index, SGAI is the } \\
\text { SG\&A index, } L V G I \text { is the leverage index, and TATA is total } \\
\text { accruals to total assets }\end{array}$ \\
\hline$A C C_{-} Q U A L_{i t}$ & $\begin{array}{l}\text { Accrual quality from Dechow and Dichev (2002), defined as the } \\
\text { inverse of the residual from the following equation: } \\
T A_{i t}= \\
\alpha_{0}+\alpha_{1} C F F O_{i t-1}+\alpha_{2} C F F O_{i t}+\alpha_{3} C F F O_{i t+1}+\alpha_{4} A T_{i t-1}+\varepsilon_{i t}\end{array}$ \\
\hline$B A N K R \_R I S K_{i t}$ & $\begin{array}{l}\text { An indicator variables that equals one if the Altman Z-score is } \\
\text { less than } 1.8 \text { and zero otherwise. The Z-score is equal to } \\
1.2 W C+1.4 R E+3.3 E B I T+0.6 M T B+1.0 S A L E S \text {, where } \\
W C \text { is working capital divided by total assets, } R E \text { is retained } \\
\text { earnings divided by total assets, EBIT is earnings before } \\
\text { interest and taxes divided by total assets, } M T B \text { is market value } \\
\text { of equity divided by book value of equity, and } S A L E S \text { is sales } \\
\text { divided by total assets. }\end{array}$ \\
\hline
\end{tabular}




\begin{tabular}{|c|c|}
\hline$L I T_{i t}$ & $\begin{array}{l}\text { An indicator that equals one if the observation falls into one of } \\
\text { the industries identified by Ho et al. (2012) as high litigation risk } \\
\text { and zero otherwise. High litigation risk industries include } \\
\text { biotechnology (SIC codes } 2833-2836 \text { ), computers (SIC codes } \\
3570-3577 \text { and } 7370-7374 \text { ), electronics (SIC codes 3600-3674), } \\
\text { and retailing (SIC codes 5200-5961) }\end{array}$ \\
\hline NONSTD $D_{i t}$ & $\begin{array}{l}\text { An indicator that equals one if the firm received a non-standard } \\
\text { audit opinion (Compustat AUOP equal to } 2,3,5 \text {, or } 0 \text { ) and zero } \\
\text { otherwise }\end{array}$ \\
\hline$T E N U R E_{i t}$ & $\begin{array}{l}\text { The auditor's tenure with the client, which takes integer values } \\
\text { from one to } 10 \text { indicating the number of years the auditor has } \\
\text { been engaged with the client. A value of } 10 \text { indicates the auditor } \\
\text { has been engaged with the client for } 10 \text { or more years. }\end{array}$ \\
\hline$B I N G N_{i t}$ & $\begin{array}{l}\text { An indicator variable that equals one if the auditor is a Big-N } \\
\text { firm and zero otherwise. }\end{array}$ \\
\hline$A G E_{i t}$ & Firm age measured as the time since its initial public offering. \\
\hline$A T_{i t}$ & Total assets. \\
\hline$R E S I G N_{i t}$ & $\begin{array}{l}\text { An indicator variable that equals one if the auditor change was } \\
\text { self-reported as an auditor resignation and zero otherwise. }\end{array}$ \\
\hline$D U A L \_8 K_{i t}$ & $\begin{array}{l}\text { An indicator variable that equals one if the firm reported the } \\
\text { auditor change using dual 8-K filings, and zero if it reported the } \\
\text { change using a single 8-K filing. }\end{array}$ \\
\hline$D U A L \_A N D \_R E S I G N_{i t}$ & $\begin{array}{l}\text { The multiple of } D U A L \_8 K_{i t} \text { and } R E S I G N_{i t} \text {. This variable } \\
\text { identifies the cases where the auditor change is both reported as } \\
\text { a resignation by the firm and disclosed through dual } 8-\mathrm{K} \text { filings. }\end{array}$ \\
\hline
\end{tabular}




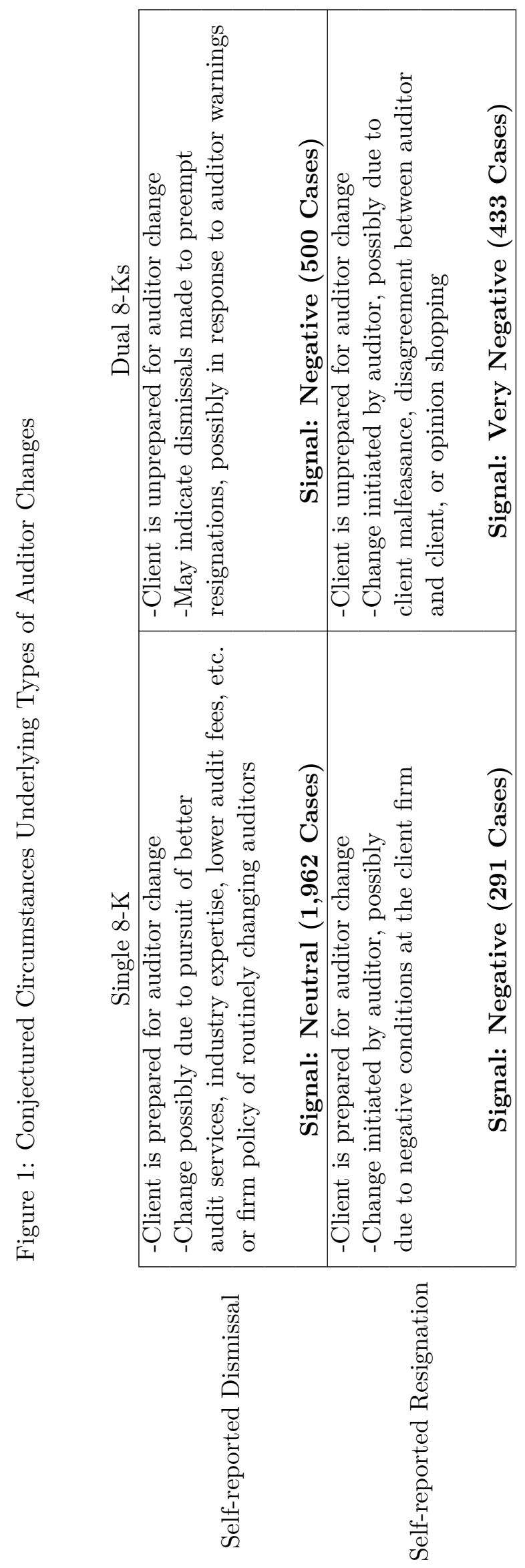




Table 2: Predicting Auditor Changes

\begin{tabular}{|c|c|c|}
\hline VARIABLES & $\begin{array}{c}(1) \\
A U D C H G_{i t}\end{array}$ & $\begin{array}{c}(2) \\
A U D C H G_{i t}\end{array}$ \\
\hline$A B S \_D A_{i t-1}$ & $\begin{array}{c}6.12 \mathrm{e}-06 \\
(1.070)\end{array}$ & \\
\hline$A B S \_P O S \_D A_{i t-1}$ & & $\begin{array}{c}2.51 \mathrm{e}-05^{* * * *} \\
\quad(4.726)\end{array}$ \\
\hline$A B S \_N E G \_D A_{i t-1}$ & & $\begin{array}{c}2.57 \mathrm{e}-06 \\
(0.615)\end{array}$ \\
\hline$M A N I P U L A T E_{i t-1}$ & $\begin{array}{c}0.00702^{* *} \\
(2.207)\end{array}$ & $\begin{array}{c}0.00695^{* *} \\
(2.184)\end{array}$ \\
\hline$A C C \_Q U A L_{i t-1}$ & $\begin{array}{c}-1.50 \mathrm{e}-06^{* *} \\
(-2.118)\end{array}$ & $\begin{array}{c}-1.49 \mathrm{e}-06^{* *} \\
(-2.110)\end{array}$ \\
\hline$N O A_{i t-1}$ & $\begin{array}{c}2.76 \mathrm{e}-06 \\
(0.585)\end{array}$ & $\begin{array}{c}2.73 \mathrm{e}-06 \\
(0.580)\end{array}$ \\
\hline$B A N K R \_R I S K_{i t-1}$ & $\begin{array}{c}0.0352^{* * *} \\
(7.889)\end{array}$ & $\begin{array}{c}0.0350^{* * *} \\
(7.842)\end{array}$ \\
\hline$L I T_{i t-1}$ & $\begin{array}{c}-0.00850^{* * *} \\
(-2.622)\end{array}$ & $\begin{array}{c}-0.00852^{* * *} \\
(-2.629)\end{array}$ \\
\hline NONSTD $D_{i t-1}$ & $\begin{array}{c}-0.0711^{* * *} \\
(-9.894)\end{array}$ & $\begin{array}{c}-0.0734^{* * *} \\
(-9.355)\end{array}$ \\
\hline$M T B_{i t-1}$ & $\begin{array}{c}0.000119 \\
(1.368)\end{array}$ & $\begin{array}{c}0.000119 \\
(1.370)\end{array}$ \\
\hline$T E N U R E_{i t-1}$ & $\begin{array}{c}-0.00175^{* * *} \\
(-3.767)\end{array}$ & $\begin{array}{c}-0.00174^{* * *} \\
(-3.743)\end{array}$ \\
\hline$B I N G N_{i t-1}$ & $\begin{array}{c}-0.0109^{* * *} \\
(-2.971)\end{array}$ & $\begin{array}{c}-0.0109^{* * *} \\
(-2.959)\end{array}$ \\
\hline$A G E_{i t-1}$ & $\begin{array}{c}-2.86 \mathrm{e}-10^{*} \\
(-1.809)\end{array}$ & $\begin{array}{c}-2.91 \mathrm{e}-10^{*} \\
(-1.835)\end{array}$ \\
\hline$A T_{i t-1}$ & $\begin{array}{c}-2.46 \mathrm{e}-07^{* * *} \\
(-7.212)\end{array}$ & $\begin{array}{c}-2.46 \mathrm{e}-07^{* * *} \\
(-7.210)\end{array}$ \\
\hline Constant & $\begin{array}{c}0.0535^{* * *} \\
(11.72)\end{array}$ & $\begin{array}{c}0.0535^{* * *} \\
(11.72)\end{array}$ \\
\hline Observations & 16,940 & 16,940 \\
\hline R-squared & 0.012 & 0.013 \\
\hline
\end{tabular}

See Appendix A for variables definitions. 
Table 3: Determinants of Dual 8-K Filings and Auditor Resignations

\begin{tabular}{|c|c|c|}
\hline VARIABLES & $\begin{array}{c}(1) \\
D U A L \_8 K_{i t}\end{array}$ & $\begin{array}{c}(2) \\
R E S I G N_{i t}\end{array}$ \\
\hline$A B S \_P O S \_D A_{i t-1}$ & $\begin{array}{c}2.09 \mathrm{e}-05^{* * *} \\
(12.96)\end{array}$ & $\begin{array}{c}2.04 \mathrm{e}-05^{* * *} \\
(12.86)\end{array}$ \\
\hline$A B S \_N E G_{-} D A_{i t-1}$ & $\begin{array}{c}-1.46 \mathrm{e}-05^{* * *} \\
(-7.426)\end{array}$ & $\begin{array}{c}-1.51 \mathrm{e}-05^{* * *} \\
(-8.102)\end{array}$ \\
\hline$M A N I P U L A T E_{i t-1}$ & $\begin{array}{c}0.0970 * * * \\
(2.634)\end{array}$ & $\begin{array}{l}0.0221 \\
(0.669)\end{array}$ \\
\hline$A C C_{-} Q U A L_{i t-1}$ & $\begin{array}{c}-0.000103^{*} \\
(-1.791)\end{array}$ & $\begin{array}{c}-1.65 \mathrm{e}-05 \\
(-0.813)\end{array}$ \\
\hline$N O A_{i t-1}$ & $\begin{array}{c}-9.58 \mathrm{e}-05^{* * *} \\
(-3.227)\end{array}$ & $\begin{array}{c}0.000145^{* * *} \\
(5.290)\end{array}$ \\
\hline$B A N K R \_R I S K_{i t-1}$ & $\begin{array}{l}-0.0270 \\
(-0.718)\end{array}$ & $\begin{array}{l}0.00547 \\
(0.159)\end{array}$ \\
\hline$L I T_{i t-1}$ & $\begin{array}{l}-0.0216 \\
(-0.516)\end{array}$ & $\begin{array}{l}0.100 * * \\
(2.438)\end{array}$ \\
\hline$M T B_{i t-1}$ & $\begin{array}{c}-0.000143 \\
(-1.536)\end{array}$ & $\begin{array}{c}-0.000343^{* * *} \\
(-3.416)\end{array}$ \\
\hline$T E N U R E_{i t-1}$ & $\begin{array}{l}0.00328 \\
(0.597)\end{array}$ & $\begin{array}{l}0.00341 \\
(0.688)\end{array}$ \\
\hline$B I N G N_{i t-1}$ & $\begin{array}{l}-0.0240 \\
(-0.603)\end{array}$ & $\begin{array}{c}-0.195^{* * *} \\
(-5.326)\end{array}$ \\
\hline$A G E_{i t-1}$ & $\begin{array}{c}-2.21 \mathrm{e}-09 \\
(-1.183)\end{array}$ & $\begin{array}{c}2.04 \mathrm{e}-09 \\
(1.218)\end{array}$ \\
\hline$A T_{i t-1}$ & $\begin{array}{c}-6.79 \mathrm{e}-06^{* *} \\
(-2.432)\end{array}$ & $\begin{array}{c}-6.21 \mathrm{e}-06^{* * *} \\
(-4.134)\end{array}$ \\
\hline Constant & $\begin{array}{c}0.304^{* * *} \\
(5.708)\end{array}$ & $\begin{array}{c}0.272^{* * *} \\
(5.653)\end{array}$ \\
\hline Observations & 664 & 664 \\
\hline R-squared & 0.026 & 0.096 \\
\hline
\end{tabular}


Table 4: Analysis of Likely Manipulators and High-Bankruptcy-Risk Firms

\begin{tabular}{|c|c|c|c|c|}
\hline & (1) & $(2)$ & (3) & (4) \\
\hline VARIABLES & $M A N I P U L A T E_{i t}$ & $M A N I P U L A T E_{i t}$ & $B A N K R \_R I S K_{i t}$ & $B A N K R \_R I S K_{i t}$ \\
\hline \multirow[t]{2}{*}{$D U A L \_8 K_{i t+1}$} & $0.115^{* *}$ & 0.0624 & -0.0348 & $-0.0923^{*}$ \\
\hline & $(2.556)$ & $(1.143)$ & $(-0.826)$ & $(-1.882)$ \\
\hline \multirow[t]{2}{*}{$R E S I G N_{i t+1}$} & -0.00911 & -0.0898 & 0.0198 & -0.0703 \\
\hline & $(-0.181)$ & $(-1.323)$ & $(0.409)$ & $(-1.086)$ \\
\hline \multirow{2}{*}{$D U A L \_A N D \_R E S I G N_{i t+1}$} & & $0.170^{*}$ & & $0.189 * *$ \\
\hline & & $(1.731)$ & & $(2.034)$ \\
\hline \multirow[t]{2}{*}{$A B S \_P O S \_D A_{i t}$} & $1.41 \mathrm{e}-05^{* * *}$ & $1.23 \mathrm{e}-05^{* * *}$ & $1.88 \mathrm{e}-05^{* * *}$ & $1.68 \mathrm{e}-05^{* * *}$ \\
\hline & $(6.745)$ & $(5.297)$ & $(9.545)$ & $(7.512)$ \\
\hline \multirow[t]{2}{*}{$A B S \_N E G \_D A_{i t}$} & $2.30 \mathrm{e}-05^{* * *}$ & $2.22 \mathrm{e}-05^{* * *}$ & $2.32 \mathrm{e}-05^{* * *}$ & $2.23 \mathrm{e}-05^{* * *}$ \\
\hline & $(10.08)$ & $(9.614)$ & $(11.43)$ & $(10.81)$ \\
\hline \multirow[t]{2}{*}{$M A N I P U L A T E_{i t}$} & & & 0.0239 & 0.0186 \\
\hline & & & $(0.629)$ & $(0.490)$ \\
\hline \multirow[t]{2}{*}{$A C C \_Q U A L_{i t}$} & $6.12 \mathrm{e}-05$ & $5.78 \mathrm{e}-05$ & $0.000203^{* * *}$ & $0.000198^{* * *}$ \\
\hline & $(0.639)$ & $(0.604)$ & $(2.898)$ & $(2.834)$ \\
\hline \multirow[t]{2}{*}{$N O A_{i t}$} & $0.000148^{* * *}$ & $0.000159^{* * *}$ & $9.69 \mathrm{e}-05^{* * *}$ & $0.000110^{* * *}$ \\
\hline & $(4.845)$ & $(5.421)$ & $(3.306)$ & $(3.533)$ \\
\hline \multirow[t]{2}{*}{$B A N K R \_R I S K_{i t}$} & 0.0257 & 0.0199 & & \\
\hline & $(0.629)$ & $(0.490)$ & & \\
\hline \multirow[t]{2}{*}{$L I T_{i t}$} & 0.0451 & 0.0386 & $0.0922^{* *}$ & $0.0845^{*}$ \\
\hline & $(0.990)$ & $(0.846)$ & $(2.071)$ & $(1.899)$ \\
\hline \multirow[t]{2}{*}{$M T B_{i t}$} & $-9.39 \mathrm{e}-06$ & $-3.11 \mathrm{e}-05$ & $-8.55 \mathrm{e}-06$ & $-3.27 \mathrm{e}-05$ \\
\hline & $(-0.0407)$ & $(-0.132)$ & $(-0.0413)$ & $(-0.159)$ \\
\hline \multirow[t]{2}{*}{$T E N U R E_{i t}$} & $-0.0135^{* *}$ & $-0.0131^{* *}$ & $0.00966^{*}$ & $0.00994^{*}$ \\
\hline & $(-2.332)$ & $(-2.273)$ & $(1.666)$ & $(1.714)$ \\
\hline \multirow[t]{2}{*}{$B I N G N_{i t}$} & $-0.0742^{*}$ & $-0.0888^{* *}$ & $-0.224 * * *$ & $-0.239 * * *$ \\
\hline & $(-1.729)$ & $(-2.021)$ & $(-5.474)$ & $(-5.841)$ \\
\hline \multirow[t]{2}{*}{$A G E_{i t}$} & $-4.66 \mathrm{e}-10$ & $-4.57 \mathrm{e}-10$ & $-9.30 \mathrm{e}-10$ & $-9.17 \mathrm{e}-10$ \\
\hline & $(-0.231)$ & $(-0.228)$ & $(-0.482)$ & $(-0.475)$ \\
\hline \multirow[t]{2}{*}{$A T_{i t}$} & $8.13 \mathrm{e}-06^{* *}$ & $8.10 \mathrm{e}-06^{* *}$ & $1.01 \mathrm{e}-05^{* *}$ & $1.00 \mathrm{e}-05^{* *}$ \\
\hline & $(2.050)$ & $(2.027)$ & $(2.307)$ & $(2.300)$ \\
\hline \multirow[t]{2}{*}{ Constant } & $0.489 * * *$ & $0.511^{* * *}$ & $0.425^{* * *}$ & $0.450^{* * *}$ \\
\hline & $(8.678)$ & $(8.926)$ & $(7.687)$ & $(7.941)$ \\
\hline Observations & 664 & 664 & 664 & 664 \\
\hline R-squared & 0.038 & 0.043 & 0.077 & 0.082 \\
\hline
\end{tabular}

*** $\mathrm{p}<0.01,{ }^{* *} \mathrm{p}<0.05, * \mathrm{p}<0.1$. See Appendix A for variables definitions. 